\title{
On the Integration of Socialist Core Values into Ideological and Political Education in Colleges and Universities
}

\author{
Yuxia Ding \\ Wuhan Donghu University, Wuhan Hubei, 430212, China
}

Keywords: Socialist core values, Integrity, Ideological and political teaching.

\begin{abstract}
The socialist core values and the ideological and political courses in colleges and universities have a high degree of consistency in value orientation. It is of great practical significance to promote the integration of socialist core values into the whole process of ideological and political education in colleges and universities, to improve the effectiveness of ideological and political education, to cultivate qualified architects and reliable successors.
\end{abstract}

\section{Introduction}

The 18th National Congress of the Communist Party of China (CPC) promised to advocate patriotism, professionalism, integrity and friendliness, and actively cultivate and practice the socialist core values, advocating prosperity, democracy, civilization, harmony, advocating freedom, equality, justice and rule of law. The socialist core values play the role of ideological guidance, value orientation and behavioral norms for economic and social development. It is of great and far-reaching significance to cultivate the core values of socialism among college students in the social transformation of values diversified. It is an important way to improve the ideological and political quality and moral quality of college students as the main channel and main position of ideological and political education of college students. The integration of socialist core values into ideological and political education in colleges and universities is not only a political task, but also a theoretical duty that should be assumed by ideological and political education in colleges and universities.

\section{Importance of Carrying out Socialist Core Values Education in Ideological and Political Education in Colleges and Universities}

Colleges and universities are the main places for cultivating socialist qualified builders and reliable successors, and have the guiding, spreading, radiating and leading role in the cultivation of socialist core values. Ideological teaching is an important way and main way for college students to cultivate socialist core values. The most important role of ideological and political education in colleges and universities is to use the theoretical achievements of Marxism in China to organize the majority of young students to ensure that the cultivated college students are in line with the needs of socialist construction. It is of great practical significance to carry out socialist core values education vigorously in ideological and political education in colleges and universities.

The integration of socialist core values into ideological and political affairs is the need to consolidate the socialist ideology in colleges and universities

Colleges and universities are the forefront of the ideological struggle, if Marxism does not occupy the dominant position in the field of ideology, then a variety of other social trends will go to occupation. Because colleges and universities shoulder the historical mission of cultivating socialist builders and successors, it is essential to ensure that the dominant position of socialist ideology in colleges and universities is important to consolidate the socialist ideology in our country. In the university to open 
ideological and political lessons, embodies the essential characteristics of the socialist university. The ideological and political affairs of colleges and universities have distinct ideology. If the core values of socialism are lost, the ideological and political education will lose its direction and lose the legitimacy and rationality of its existence. To promote the integration of socialist core values into the teaching of ideological and political education in colleges and universities is to ensure that the socialist nature of ideological and political education is to clearly carry out socialist ideology education for college students. As the ideological and political education of the main positions of ideological and political education, only to actively cultivate the socialist core values of college students in order to really cultivate the Chinese characteristics of socialism builders and successors to complete the task, to consolidate the socialist ideology in the university the role of play well.

\section{The integration of socialist core values into ideological and political education is the need to realize the goal of cultivating college}

The ultimate goal of ideological and political education in colleges and universities is to cultivate the builders and successors of the cause of socialism with Chinese characteristics. In accordance with the requirements of this goal, solid, comprehensive professional knowledge and skills, excellent physical and mental health and good ideological and moral qualities are essential for college students, but the most important, the core of the quality of ideological and moral qualities. And actively cultivate the socialist core values. To guide the university students to believe in the guiding ideology of Marxism, firmly take the common ideals of the road of socialism with Chinese characteristics, carry forward the national spirit with patriotism as the core and the spirit of the times with reform and innovation as the core, practice the socialist concept of honor and disgrace, The ideological and moral foundation of all - round development is the inherent requirement of college students' adulthood, and it is the ideological guarantee to realize the goal of cultivating college in our country.

\section{Basic Requirements of the Integration of the Socialist Core Values into the Ideological and Political Courses in Colleges and Universities}

\section{Scientifically understand the whole of the four courses of ideological and political education}

Four courses of ideological and political education have their own different teaching content, these contents have a large span, macro, strong teaching content and other common features. In order to achieve the teaching objectives of each course, we must first accurately grasp the integrity of each course itself. "Introduction" mainly teaches the historical process of Marxism in China and the basic content of the Marxist theory of China, that is, how to understand Marxism and how to develop Marxism for the Chinese Communists. This issue can cover and guide the historical and theoretical understanding of the theoretical activities of the Party in different historical periods and stages of development. Its teaching content has a direct relationship with the guiding ideology of the Communist Party of China as a ruling party. The teaching effect of this course is related to the theoretical and political identity of the university students on the ruling position of the Communist Party of China. Marxism in China contains two basic propositions, one is what Marxism, the second is what is Marxism in China. The "principle" teaching in the holistic view is mainly embodied in two levels, one is the world outlook and methodology of dialectical materialism, the second is the basic law of historical materialism on the development of human society and its basic laws in capitalism and socialism The general characteristics of the manifestation. By teaching students to understand what is Marxism, which involves the understanding of the premise of Marxism in China. Without this premise, students can not really understand the Chinese Communist Party in the theory and practice of innovation. To understand the process of Marxism in China, we must understand the history of China's development in modern times, understand the Chinese Communist Party on the existence and development of the historical environment. The outline of the holistic view mainly teaches the special logic of China's social development since modern times. How can the Chinese Communist Party combine Marxism with Chinese historical conditions in modern times and explore the road of 
socialism with Chinese characteristics. "Basic" is the concrete application of the above theory, mainly to the socialist core values of the cultivation of the main line of logic, infiltration of the education requirements of college students, specifically, first, the use of Marxist education students to the basic position, The essence of life, to establish the ideal and faith, to create the value of life, distinguish right from wrong, temper personal character, consciously law enforcement. Second, to guide students to firmly establish the socialist core values, and consciously abide by the norms of ethics and laws and regulations. Third, to guide students to enhance the spiritual realm, so that the socialist core values into a firm belief, externalized into practical action, the formation of good moral quality and legal awareness. In general, the four courses not only exist in their own integrity, but also between each other, there is also an internal relationship.

\section{The socialist core values are effectively integrated into the teaching of ideological and political education in the holistic view}

First of all, in the teaching of the concept, adhere to the direction of science, humanities are unified. Directionality is a firm and correct political principle and position. The fundamental task of ideological and political education is to carry out the socialist ideology of college students, that is, to cultivate the socialist core values of education, so that students in the face of a variety of complex ideological environment can always be the core values of socialism as a guide, firm position, Diligent study, and strive to become talent, and thus become the ideal of socialism with Chinese characteristics and beliefs qualified personnel. This is determined by the nature and mission of the thought. Scientificity refers to the ideological and political affairs to rational people, to the scientific principles and the basic knowledge of the students convincing. Through the teacher's explanation, so that students have a scientific theoretical knowledge, the real understanding of nurturing and practice the socialist core values for their own growth and positive impact. Humanity refers to the ideological and political affairs to people-oriented. To realize the free and comprehensive development of human beings is the fundamental value goal pursued by Marxism. The ideological and political lesson is to cultivate man-made purpose, humanistic education under the concept of humanistic education, and emphasizes respect for people and caring people. From the needs of college students, listen carefully to their voices, the organization close to the students of teaching activities, so that they feel the role of ideological and political significance and significance, so as to improve the effectiveness of teaching. In short, from the perspective of direction, science and humanistic education, the socialist core values can be effectively integrated into the teaching of ideological and political education in colleges and universities.

Second, in the teaching team, the establishment of teaching team, consolidate the organizational basis of the overall teaching. At present, there are two main ways of ideological and political education, one is drawing teaching, the second is cohesive teaching. Latin style teaching is by a teacher to finish the whole course, cohesive teaching is by a number of teachers to speak the same course. From the actual effect of teaching, the current two methods are inadequate. As a result of the task of teaching, the limitations of teachers' professional knowledge can not achieve the goal of teaching well. The cohesive teaching is not coordinated due to the lack of coordination among teachers, especially because of the disagreement between the goals and methods of the overall teaching of the course, which makes the teaching content scattered and deviated from the subject of ideological and political education in varying degrees. Integral teaching requires a cohesive teaching model based on a teaching team. This model has two characteristics, one is the teaching team is built on the basis of the overall requirements, with a holistic teaching philosophy, and to scientific research based on a reasonable teaching design. Second, cohesive teaching has internal teaching integration, focus on the overall teaching philosophy as a guide to the overall design of the curriculum, carefully refine the problem, on the basis of the overall highlight of the teaching of scientific awareness, awareness of law and sense of faith, And to design specific teaching content.

Again, in teaching methods, efforts to improve classroom teaching, innovation and practical teaching, and strengthen the ideological and political teaching of the main role of the classroom. In 
recent years, our school in the "learning as the main body, as the main line; knowledge transfer and ability training, improve the quality of both" principle, and constantly deepen the teaching reform, innovative teaching methods, and gradually formed a set of interactive teaching methods, Including a variety of teaching methods such as scene drama, daily practice practice, growth diary method, pre-class news broadcast method, new students talk theory, multimedia teaching method, social practice teaching method and so on. Classroom teaching is a kind of bilateral activities, our school ideological and political lessons have been interactive teaching as the main teaching methods, specifically for the interactive classroom discussion.

Interactive discussion mainly refers to the combination of classroom teaching content and students generally concerned about the reality of the problem, the teacher selected some questions as a discussion, students prepared in advance, in the classroom teaching to set aside some time to discuss. Teachers to guide students to take the initiative to speak, so that students express their views, teachers on the basis of this depth to sum up and upgrade. Speaking at the time of the students, the teacher can discover the students' problems in the ideological and understanding, and guide the students to take the initiative to think, focus on lectures, active classroom atmosphere. Teachers can also according to teaching needs, arranged in advance of the problem, organize student group discussion. You can also design a number of interactive games, such as in the "ideological and moral cultivation and legal basis" class design appreciation exercises, lifeline games, trust tours and so on to allow students to participate. We have learned through long-term interactive discussion and teaching that this pedagogy strengthens the interaction between teachers and students, between students, activates the classroom atmosphere, and gives students the ability to think, analyze and solve problems independently. Of the targeted and persuasive, so as to establish the socialist core values.

To ensure the quality of classroom teaching at the same time, strengthen the practice of teaching links, and actively create practical teaching conditions, create a practical teaching environment, organize and guide students in-depth society, in-depth grassroots, deep into the masses, through the experience, visit, social services and other forms Accept the influence, exercise, grow, cultivate and practice the socialist core values.

Finally, in the teaching methods, make full use of digital technology, network technology, mobile communication technology as the basis of the new media, enrich the ideological and political lessons. The development of modern educational technology, represented by multimedia and network, provides a powerful technical platform for the reform of teaching mode and teaching methods of national education, including ideological and political education. Ideological and Political Affairs should closely follow the development of modern educational technology, and actively develop and make full use of all new technologies, new means, new services and new tools that help teaching, and strive to modernize teaching methods. To actively tap and use the socialist core values to cultivate the network resources, at any time to update the educational material, to strengthen online and offline teaching interactive exchange, the use of new media mass, fast, interactive, vivid and other characteristics of the practice of socialist core values of the great practice Take the initiative to show the students in a timely manner to improve the teaching and teaching of technical content and the level of modernization, and enhance the attractiveness and appeal of education and teaching activities to ensure the effectiveness of education and teaching.

\section{References}

[1] Liang Shufa.On the Principle of Holism in the Construction of Marxist Theoretical Discipline,Journal of Ideological \& Theoretical Education, 2006(7):29.

[2] Zhang Leisheng.Three levels of Marxist holism,Journal of Ideological \& Theoretical Education, 2008(2):44-47.

[3] Chen Jinlan.The Teaching of Basic Principles of Marxism Should Be Emphasized on integration,Journal of Southwest University of Science and Technology, 2009(2):86—89. 
[4] Chen Wenrong.Some Experiences in the Teaching of Ideological and Political Theory[C].He Yiguan.Reform and Teaching of Ideological and Political Theory Course - Discussion on Improving the Teaching Quality of Undergraduate Course. Beijing: Social Science Academic Press, 2008:198,200.

[5] Liu Jianjun.A Study on the Integrity of the New Program of Ideological and Political Theory Course. Ai Silin.A Study on the New System of Ideological and Political Theory and the Construction of Teachers.Beijing: Tsinghua University Press, 2008:75. 